\title{
A COMPARATIVE STUDY OF THE EFFECTIVENESS OF VYGOTSKY'S CONCEPT OF ZONE OF PROXIMAL DEVELOPMENT AND TRADITIONAL METHOD FOR TEACHING MATHEMATICS AT ELEMENTARY LEVEL
}

\author{
By \\ Aftab Ahmad Khan
}

\begin{abstract}
In Pakistan the Zone of Proximal Development (ZPD) is relatively a new concept. Earlier, only one study analyzed ZPD in graduate teacher training programmes of Allama Iqbal Open University. In contrast, present study was a classroom experiment; the purpose was to investigate the comparative effectiveness of Vygotsky's Concept of Zone of Proximal Development and Traditional Method for teaching Mathematics at Elementary Level. The design of the study was pertest-posttest control group design and the sample of 48 students equated on their prior ability in maths into 24-students experimental and control group each. The measuring instrument of the research was a self-prepared achievement test of 40 multiple-choice items in the subject of mathematics for $8^{\text {th }}$ grade level. The treatment span was for six weeks, forty minutes each day. After collecting data, it was analyzed through mean, standard deviation, coefficient of variability and $t$ - test.
\end{abstract}

Findings of the study show that the students who were taught mathematics through Vygotskyian method of Zone of Proximal Development complemented by scaffolding did better in mathematics achievement than the students taught through the conventional method.

Hence, Vygotskian model of teaching was perhaps a better substitute of traditional mode of teaching mathematics to elementary students.

\section{Introduction}

From the very beginning a child learns a lot from the interaction with others. The view that knowledge construction is collaborative and constructive in nature has been considerably emphasized by Piaget, and later by Vygotsky (Rogoff, 2001). Vygotsky, the Russian developmental psychologist, views that a child does not learn in isolation; instead learning is strongly influenced by social interaction (Vygotsky, 1993, 1994, 2004). Children's social interaction with more knowledgeable or capable persons significantly influences their way of thinking and interpreting situations. A child develops his intellect through internalizing concepts based on his own interpretation of activity, which occurs in a social setting. The communication that occurs in this setting, with more knowledgeable others (teachers, parents, peers, etc.), helps the child construct and understand the concept (Bransford, Brown, and Cocking, 2000). Thus, social interaction plays a fundamental and indispensable role in the development of cognition and social activity is crucial to child's development as a learner (Kearsely, 2002). Through this

- The writer is an M.Phil scholar at Department of Education, AIOU, Islamabad. 
interaction, less skilled members of the culture learn to use cultural tools that will help them to adapt and be successful (Santrock, 2005).

The way students interact with their parents, teachers or peers, etc., predicts important cognitive and emotional aspects of students' future behavior, including attitude towards school, academic performance (Ladd, 1990), self-concept (Buhrmester, 1990), disruptive and aggressive behavior (Coie, Dodge, and Coppotelli, 1982) and the likelihood of dropping out of school (Parker and Asher, 1987).

Vygotsky says that we can understand and describe children's cognitive capabilities when we look at two aspects of their cognitive development. First, we can determine the extent to which children can perform a task independently; this is their level of actual development. Second, we can determine the extent to which they can perform a task with assistance of a more competent individual; this is their level of potential development. There is a gap between these two levels. Vygotsky calls this gap as Zone of Proximal Development (Ormord, 1998).

\section{Level of Actual Development Level of Potential Development (Students can function independently) (Students can function dependently)}

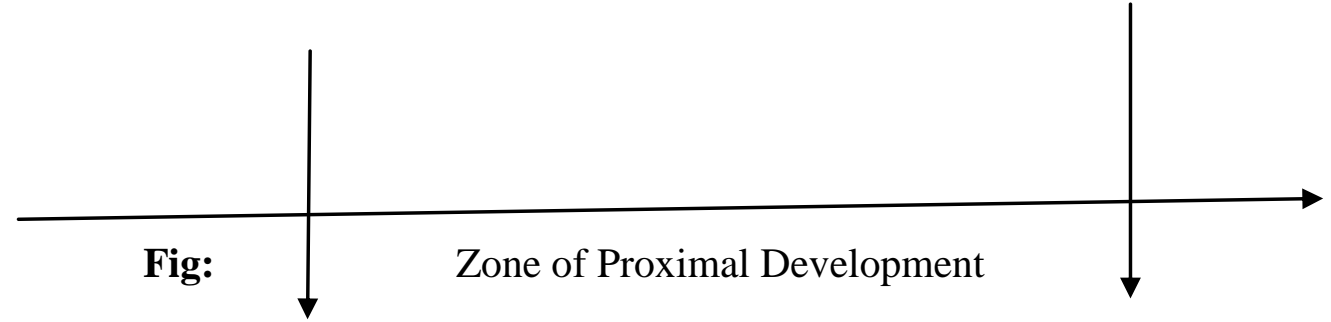

A child's zone of proximal development (ZPD) includes learning and problem-solving abilities that are just beginning to develop; abilities that are immature or are in an embryonic state. Vygotsky proposes that children learn very little from performing tasks that they can already do independently. Instead, they develop primarily by attempting tasks within their ZPD, those they can accomplish only in collaboration with more competent individuals (Ormord, 1998).

Closely related to the idea of ZPD is the concept of scaffolding (Santrock, 2001). In the process of scaffolding, the teacher helps the student master a task or concept that he is initially unable to grasp independently. The teacher offers assistance with only those skills that are beyond the student's capability. The student is allowed to complete the task, as much as possible, unassisted. The teacher only attempts to help him with tasks that are just beyond his current capability. While he is mastering the task, the teacher gradually removes his assistance and allows him to work independently. Scaffolding is actually a bridge used to build upon what students already know to arrive at something they do not know (Benson, 1997).

Vygotsky describes scaffolding instruction as supporting the learners' development by providing support and structure to get the next stage or level" (Raymond, 2000, p. 176). In scaffolded instruction, a more knowledgeable "other" provides scaffolds or support to facilitate the learner's development. The scaffolds facilitate student's ability to build on prior knowledge and internalize new information. The activities provided in scaffolding instructions are just beyond the level of what the learner can do alone (Olson and Platt, 2000). The more knowledgeable aspect provides the appropriate scaffolds, the more the learner can accomplish (with assistance) the task that he could otherwise not 
complete (Bransford, Brown and Cocking, (2000). As the learner's abilities increase, the scaffolding is progressively withdrawn. Finally, the learner is able to complete the task or master the concepts independently (Chang, Sung, and Chen, 2002).

From the last few decades, American and European psychologists and educators have shown increased interest in Vygotsky's views (Santrock, 2001). In Pakistan, it appears to be one of the first few efforts of its kind to use ZPD in the classroom, especially while teaching mathematics to elementary and secondary students. Therefore, in present study, an attempt was made to compare the effectiveness of ZPD accompanied by scaffolded instruction with the traditional method for teaching mathematics at elementary level.

\section{Objectives of the Study}

The objectives of the proposed study were:

1. To determine the achievement of $8^{\text {th }}$ class students in the

subject of mathematics before the treatment.

2. To expose the experimental group to learning experiences in the light of Vygotsky's concept of ZPD and the control group to traditional, routine teaching in the subject of mathematics.

3. To measure the achievement of $8^{\text {th }}$ class students taught through Vygotsky's concept of ZPD and students taught through the traditional chalk and talk method.

4. To compare the achievement of the control group and the experimental group after the treatment.

\section{Hypothesis of the Study}

$\mathbf{H}_{\mathbf{o}} \quad$ There is no significant difference between the mean achievement scores of the elementary students being taught mathematics through Vygotskyian method of zone of proximal development and those taught through traditional method.

$\mathbf{H}_{1} \quad$ Vygotskyian method of ZPD is better than traditional method for teaching mathematics at elementary level.

\section{Methodology}

The design of the study was a form of pure experiment known as pretest- posttest control group design. A total of 650 boy students, studying in 13 elementary schools, were the population of the study. A sample class of 48 students in $8^{\text {th }}$ class was selected randomly.

An achievement test of 40 multiple-choice items was prepared by the researcher, in the subject of mathematics at $8^{\text {th }}$ grade level. The reliability of the test was determined through using split half method Spearman Brown formula. The correlation coefficient was 0.98. The test was to be used both as pretest and posttest. The instrument was prepared in the light of the table of specification as given below:

Table - 1

Table of Specification

\begin{tabular}{|c|c|c|c|c|}
\hline Area & Knowledge & Comprehension & Application & Total \\
\hline Previous & 02 & 04 & 04 & 10 \\
\hline
\end{tabular}




\begin{tabular}{|l|l|l|l|l|}
\hline Knowledge & & & & \\
\hline Chapter 5 & 03 & 03 & 04 & 10 \\
\hline Chapter 7 & 03 & 03 & 04 & 10 \\
\hline Chapter 9 & 03 & 03 & 04 & 10 \\
\hline & 11 & 13 & 16 & 40 \\
\hline
\end{tabular}

The instrument was finalized after consulting with the experienced teachers in the field and under the guidance of advisor. The test contained 40 multiple-choice items out of which 11 items were related to the "knowledge domain", 13 items were related to the "comprehension domain" and 16 items were related to the "application domain".

A pre-test in the subject of mathematics was administered to the sample class. The class was divided into two matched groups of 24 students each. The groups were equalized on the basis of their average ability on the test. These two groups were labelled randomly as control group and experimental group. Control group was taught through traditional method and experimental group was taught through Vygotsky's Concept ZPD. Both groups were taught for six weeks.

The pre-test was also used as a post-test and was administered after the termination of the experiment to both the control and experimental groups. The scores of the post-test were recorded.

Results

Table -2

Difference between Pre-test Achievements Scores of Experimental and Control Group

\begin{tabular}{|c|c|c|c|c|c|c|}
\hline Group & $\begin{array}{c}\text { No. of } \\
\text { Students }\end{array}$ & Mean & $\begin{array}{c}\text { Standard } \\
\text { Deviation }\end{array}$ & SS & t & p \\
\hline Control & 24 & 14.0 & 4.25 & 416 & \multirow{2}{*}{0.42} & $<0.05$ \\
\hline Experimental & 24 & 13.5 & 3.97 & 462 & \\
\hline
\end{tabular}

$$
\mathrm{df}=23 \quad \mathrm{t}_{(0.05)}=2.01
$$

The above table indicates that the calculated value of $t$ is less than the table value at 0.05 levels. This means that there is no significant difference in the academic status of both the groups on their pre-test performance, which implies that both the groups are almost equal in their ability in the subject of Mathematics.

Table -3

Difference between Post test Achievements Scores of Experimental and Control Group

\begin{tabular}{|l|l|c|c|c|c|}
\hline Group & $\begin{array}{l}\text { No. } \\
\text { Students }\end{array}$ & D & SE $_{\mathbf{D}}$ & $\mathbf{t}$ & p \\
\hline Control & 24 & 10.33 & 2.14 & 4.82 & $>0.05$ \\
\hline Experimental & 24 & & & \\
\hline
\end{tabular}


As the calculated value of $t$ is greater than the table value of $t$ at 0.05 levels, this indicates that there is significant difference between the mean post-test scores of control and experimental group. Hence, the null hypothesis is rejected and it is concluded that there is significant difference between the achievements of the students being taught mathematics through traditional method and taught through ZPD at elementary level.

\section{Conclusion}

On the basis of the result of the experiment it was concluded that the equal ability students, taught through Vygotsky's method of teaching based on ZPD complimented by scaffolding, did better in mathematics than those who were taught by traditional method. Therefore ZPD complemented by the scaffolded teaching was a better method than the traditional method.

\section{Discussion}

The present study was conducted to investigate the relative effectiveness of Vygotsky's concept of ZPD and traditional method of teaching mathematics at elementary level. It was perhaps one of the pioneer efforts to use the said concept in the classroom in a Pakistani school. Earlier, Akbar, A. (2002), analyzed the ZPD in graduate teacher training programmes of Allama Iqbal Open University. But that study was not a classroom experiment.

Teaching within ZPD is basically an individualized form of teaching, while the researcher used it in the whole class in a period system. Individualized teaching/ tutoring has no time limits. One limitation of the present study was in the management of time. The researcher had to teach the new topic and to supervise the scaffolding session within 40 minutes. One possible solution of this problem was to prepare charts. The researcher prepared charts, which contained rules and solved examples of each topic. These charts remained hanging in the classroom throughout the scaffolding session. So, they not only saved the researcher's time, but also helped him to explain the topic in 10 minutes. Also, they were a continuous source of guidance during the scaffolding session and the researcher was able to scaffold students' learning of topics in 20 to 30 minutes.

Another limitation pertains to the determination of ZPD of each student. It was very difficult for the researcher to do so. However, in the class the researcher used oral questioning technique and previous achievement record of each student, in mathematics, to test the level of previous achievement.

The use of ZPD and scaffolding in the classroom was new approach for the students and almost every learning activity was within their ZPDs, so they fully participated and remained active during scaffolding sessions.

One of the possible reasons for superior performance of the experimental group might be the following. Firstly, the method was new for the students, so naturally they had better orientation towards this change and leading to better results. Secondly, every learning activity was within children's ZPD so children learnt new concepts better because these were within their potential level of development. Thirdly, researcher himself was engaged to teach the 
experimental group. So there was greater possibility that despite all efforts to remain impartial, he unintentionally paid more attention to the experimental group.

Effects of the interaction with more knowledgeable others (teacher, peer, or adult) or oneto-one tutoring (scaffolding) have been studied by several researchers. Dill and Boykin (2000) studied the influence of individual and peer tutoring in African American children and found that peer tutoring, i.e. interaction and scaffolding of peers, was more influential than individual tutoring. Such interactions with teachers, peers, or adults in a cooperative setting proved to be more helpful in children's learning (Cannella, 1993; Haynes and Gebreyesus, 1992). Similarly, Wentzel (1991), while studying older children, concluded that positive peer interaction is associated with higher levels of motivation and engagement in school. Results of Coolahan, Fantuzzo, Mendez and McDremott (2000), also show that social interaction with peer results in positive engagement in the classroom. A number of other studies also conclude that interaction with more knowledgeable others have enhanced the educational outcomes up to a reasonable extent (Cohen et. el. 1982; Mathes and Fuchs,_1994; Butler, 1991; Wasik and Slavin, 1993; Dromsky and Gambrell, 1999; Howard, 1999;_and Morrow and Woo, 1999). The results of the present study are in compliance to the above-mentioned studies. The U.S National Association for the Education of young children, (1991) and U.S. Department of Health and Human Services, (1996) also advocate social interaction in the form of peer relationship to facilitate the learning process. Because, the children who engage in peer interaction, i.e. who are scaffolded by peers, demonstrate positive learning behaviour as well as more engagement and achievement in the classroom, so education ministry and all other education managers may encourage teachers of elementary, secondary and higher levels of education to use Vygotsky's ideas of cognitive development for promoting student learning.

\section{REFERENCES}

Akbar, A. (2002). Analysis of Zone of Proximal Development (ZPD) in graduate teacher training programs of Allama Iqbal Open University and Development of a strategy to achieve ZPD incidence using Delphi Technique. Islamabad: AIOU.

Benson, B. (1997). Scaffolding: Coming to terms. English Journal, 86(7), 126-27.

Bransford, J., Brown, A., and Cocking, R. (2000). How People Learn: Brain, Mind, and Experience and School. Washington, DC: National Academy Press.

Buhrmester, D. (1990). Intimacy of friendship, interpersonal competence, and adjustment during preadolescence and adolescence. Child Development, 61, pp. 1101-1111.

Butler, S. R. (1991). Reading Program $\square$ Remedial, integrated and innovative Annals of Dyslexia, 41, 119-127.

Cannella, G. S. (1993). Learning through interaction: Shared cognitive experience, negotiation strategies and joint concept construction for young children. Early Childhood Research Quarterly, 8, 427-444. 
Chang, K., Chen, I., and Sung, Y. (2002). The effects of concept mapping to enhance text comprehension and summarization. The journal of Experimental Education 71(1), pp. 523.

Cohen, P., Kulik,J. A., Kulik, C. C. (1982). Educational outcomes of tutoring: A meta- analysis of findings. American Educational Research Journal, 19, 237-248.

Coolahan, K., Fantuzzo, J., Mendez, J., and McDermott, P. (2000). Preschool Peer Interaction and Readiness to Learn: Relationship Between Classroom Peer Play and Learning Behaviors and Conduct. Journal of Educational Psychology, 92, 458-465.

Dill, E. M., and Boykin, A. W. (2000). The comparative influence of individual, peer tutoring, and communal learning contexts on the text recall of African American Children. Journal of Black Psychology, 26, 65-78.

Dromsky, A. J., and Gambrell, L. B. (1999, April). American Reads at the University of Maryland: Practices, evaluation and implication. Panel presented at the annual meeting of the American Educational Research Association, Montreal, Quebec, Canada.

Haynes, N. M., and Gebreyesus, S. (1992). Cooperative learning: A case for African American students. School Psychology Review, 21, 577-585.

Howard, J. K. (1999, April). Project VALUE: Valid, Adult-Mediated Literacy Instruction which is Useful and Efficient. Panel presented at the annual meeting of the American Educational Research Association, Montreal, Quebec, Canada.

Kearsley, G. (2002). Social Development Theory, Retrieved October 29, 2002. from http://tip.Psychology.org/vygotsky.htm. Ladd, G. W. (1990). Having friends, keeping friends, making friends, and being linked by Peers in the classroom: predictor of children early school adjustment? Child Development, 61, pp.1081-1100

Mathe, P. G., and Fuchs, L. S. (1994). The efficacy of peer tutoring in reading for students with mild disabilities: A best-evidence synthesis. School Psychology Review, 23(1), 59-80.

Morrow, L. M., and Woo, D. G. (1999, April). The effects of American Reads tutoring program on literacy achievement and evaluation of the attitudes of teachers, tutors, and children towards the program. Panel presented at the annual meeting of the American Educational Research Association, Montreal, Quebec, Canada.

Olson, J. W. and Platt, J. (2000). The Instructional Cycle: Teaching children and adolescents with special needs. Upper Saddler River, NJ: Prentice Hall, Inc.

Ormord, J. E. (1998). Educational Psychology (2 ${ }^{\text {nd }}$ Ed.). NJ: Prentice Hall, Inc.

Parker, J. G., and Asher, S. R. (1987). Peer relations and later personal adjustment: Are lowaccepted children "at risk"? Psychological Bulletin, 102, pp. 357-389. 
Raymond, E. (2000). Cogitative Characteristic. Learners with Mild Disabilities. (P.169-201). Neeham Heights, MA: Allen and Bacon.

Rogoff, B. (2001), Children learning in the zone of proximal development. San Francisco: JoseyBass.

Santrock, J. W. (2001). Educational Psychology. Boston: McGraw Hill.

Santrock, J, W. (2005). Adolescence (10 ${ }^{\text {th }}$ Ed.). Boston McGraw Hill.

U. S. Department of Health and Human Services. (1996). Final Rule $\square$ Head Start Performance Standards (Publication No. 45 CFR Part 1304). Washington, DC: U. S. Government Printing Office.

U. S. National Association for the Education of Young Children. (1991). Guideline for appropriate curriculum content and assessment in program serving children ages 3 through 8 . Young Children, 41(6), 21-38.

Vygotsky, L. S. (1993). Studies on the history of behavior: ape, primitive, and child. (V. I. Golod and J.E. Knox, Trans. and Eds.). Hillsdale, NJ: Lawernce Erlbaum Associates.

Vygotsky, L. S. (1994). The Vygotsky Reader. (R. Van Der Veer and J. Valsiner, Eds.). Oxford, UK; Cambridge, MA: Blackwell.

Vygotsky, L. S. (2004). The Essential Vygotsky. (R. W. Rieber and D. K. Robinson, Eds.). NY: Kluwer Academic/Plenum Publishers.

Wasik, B. A., and Slavin, R. E. (1993). Preventing early reading failure with one-to-one tutoring: A review of five programs. Reading Research Quarterly, 28, 178-200.

Wentzel, K. R. (1991). Classroom competence may require more than intellectual ability: Reply to Jussim (1991). Journal of Educational Psychology, 83, 156-158. 